OPEN ACCESS

Edited by:

Jordi Pérez-Tur

Superior Council of Scientific

Investigations (CSIC), Spain

Reviewed by:

Chiara Di Resta,

Vita-Salute San Raffaele

University, Italy

Habib Georges Rizk, Medical University of South Carolina,

United States

*Correspondence: Patricia Perez-Carpena percarpena@gmail.com

Specialty section:

This article was submitted to

Genetics of Common and Rare

Diseases,

a section of the journal

Frontiers in Genetics

Received: 08 June 2020

Accepted: 29 July 2020

Published: 31 August 2020

Citation:

Paz-Tamayo A, Perez-Carpena $P$ and Lopez-Escamez JA (2020) Systematic

Review of Prevalence Studies and Familial Aggregation in Vestibular Migraine. Front. Genet. 11:954. doi: 10.3389/fgene.2020.00954

\section{Systematic Review of Prevalence Studies and Familial Aggregation in Vestibular Migraine}

\author{
Ana Paz-Tamayo ${ }^{1}$, Patricia Perez-Carpena ${ }^{2,3 *}$ and Jose A. Lopez-Escamez ${ }^{1,3,4}$ \\ ${ }^{1}$ Division of Otolaryngology, Department of Surgery, Universidad de Granada, Granada, Spain, ${ }^{2}$ Department of \\ Otolaryngology, Instituto de Investigación Biosanitaria ibs.GRANADA, Hospital Universitario San Cecilio, Granada, Spain, \\ ${ }^{3}$ Otology \& Neurotology Group CTS495, Department of Genomic Medicine, GENYO - Centre for Genomics and Oncological \\ Research - Pfizer/University of Granada/Junta de Andalucía, PTS, Granada, Spain, ${ }^{4}$ Department of Otolaryngology, Instituto \\ de Investigación Biosanitaria ibs. GRANADA, Hospital Universitario Virgen de las Nieves, Granada, Spain
}

Background: Vestibular migraine (VM) is complex disorder consisting of episodes of migraine and vertigo with an estimated prevalence of 1-3\%. As migraine, it is considered that VM has genetic predisposition; however, evidence to support a genetic contribution has not been critically appraised.

Objective: The aim of this systematic review is to assess available evidence in scientific publications to determine the role of inheritance in VM.

Methods: After performing the quality assessment of the retrieved records, 31 studies were included (24 epidemiological reports and 7 genetic association studies in families or case-control in candidate genes). We gathered data about prevalence of VM in different populations and in families, and also about the genetic findings reported. In addition, other variables were considered to assess the heritability of VM, such as the ancestry, the age of onset or the familial history of vertigo and migraine.

Results: The estimated prevalence of VM was different between black (3.13\%), white (2.64\%) and Asian (1.07\%) ethnicities. The reported prevalence of VM in migraine patients is higher in European countries (21\%) than in Asian countries (10\%). Moreover, the prevalence of the migraine-vertigo association in families is 4-10 times higher than the prevalence reported in the general population (sibling recurrence risk ratio $\lambda_{\mathrm{s}}=$ 4.31-10.42). We also found that the age of onset is lower in patients with simultaneous onset of symptoms and in those who have familial history for migraine and/or vertigo, suggesting anticipation. Although some genetic studies have reported few allelic variants associated to MV, replication studies are needed to validate these results.

Conclusions: The available evidence to support heritability in VM is limited. Variability in prevalence depending on ethnicity and geographic location suggests a combined genetic and environmental contribution to VM. However, the familial aggregation observed in VM support genetic and shared familial environmental effects that remarks the necessity of twins and adoptees-based epidemiological studies to estimate its heritability.

Keywords: vestibular migraine, heritability, prevalence, genetics, vestibular disorders, epidemiology 


\section{INTRODUCTION}

Migraine is a complex multifactorial disorder characterized by headache attacks associated with a constellation of neurological symptoms. In approximately one-third of patients, headaches are preceded by transient focal sensorial symptoms, so-called auras, involving visual and hearing systems. Genetic factors contribute to the clinical spectrum of migraine and multiple common variants have been associated with migraine with and without aura (Sutherland and Griffiths, 2017; de Boer et al., 2019). The diagnostic criteria of migraine were standardized according to the International Headache Society (Headache Classification Committee of the International Headache Society, 2018). Epidemiological evidence supports that familial aggregation with an early disease onset, particularly for the aura subtype, indicating a higher genetic susceptibility in migraine with aura (Russell et al., 1996; Ulrich et al., 1999; Mulder et al., 2003; Stewart et al., 2006).

Vestibular migraine (VM) consist of a subgroup of patients with migraine where the sensorial symptoms involve the vestibular system. VM is characterized by recurrent episodes of vertigo, a current or past history of migraine and simultaneous occurrence of both symptoms during crisis (Li et al., 2019). VM is one of the most common causes of recurrent vertigo. Prevalence studies have described MV as a frequent disease (0.9-2.7\%), with variations in the frequency according to the population of study (Neuhauser et al., 2006; von Brevern et al., 2007; Formeister et al., 2018). However, VM is underdiagnosed, due to variability and overlap of symptoms with other causes of vertigo and to normal neurological examination and neuroimaging (Li et al., 2019).

The diagnostic criteria for VM were jointly developed by the Barany Society and the International Headache Society in 2012 (Lempert et al., 2012), and they differentiate probable and definite VM. Criteria for definite VM were included in the appendix of the 3rd edition of the International Classification of Headache Disorders (ICHD-III), one step forward to consider VM as an independent entity (Headache Classification Committee of the International Headache Society, 2018).

Migraine is a complex and multifactorial disorder with a large genetic component (Sutherland and Griffiths, 2017). Therefore, VM could also present a genetic predisposition (Knezevic et al., 2018; Rainero et al., 2019).

Familial clustering in VM has been occasionally observed, supporting the hypothesis of a genetic contribution to VM (Espinosa-Sanchez and Lopez-Escamez, 2015). Some studies reported families with an autosomal dominant inheritance with a moderate to high penetrance; however, no causative mutations have been found (Kim et al., 1998; von Brevern et al., 2006). Moreover, some loci segregating VM have been identified by linkage analysis in some few families with affected individuals in 22q12 (Lee et al., 2006) and 5q35 (Bahmad et al., 2009). These results suggest polygenic inheritance for VM; however, evidence to support a genetic contribution has not been critically appraised, and more research in this area is needed.

The aim of this systematic review is to assess available evidence in scientific publications to determine the role of inheritance in VM. So, we gathered information about the prevalence of
VM in different populations, including family studies and twin studies, and we analyzed the quality of reported findings in genetic studies.

\section{MATERIALS AND METHODS}

\section{Study Design}

This review has followed the Preferred Reported Items for Systematic Reviews and Meta-Analyses (PRISMA) guidelines (Moher et al., 2009) (Supplementary Table 1).

According to the methodology for systematic reviews, the issues related to the PICO question are listed below and the studies have been selected according to the following characteristics:

- Participants: Patients diagnosed with VM.

- Intervention: Measurement of prevalence of the disease, estimation of familial aggregation, estimation of concordance in monozygotic/dizygotic twins, measurement of the presence of certain genes or loci, measurement of other demographic characteristics (age of onset of symptoms, familial history of migraine, vertigo or the vertigo-headache association).

- Control: Controlled and uncontrolled studies.

- Main results: Variation in the prevalence of the disease among different populations, families and twins compared to the general population.

- Secondary results: Reported associations with certain genes or loci; variation in the prevalence of other demographic characteristics (age of onset or family history).

- Study design: Case-control studies, family studies, twin concordance studies, cross-sectional studies and case series.

\section{Search Strategy}

The article search was performed on May 23, 2020 in the PubMed and Scopus databases, with the following combination of keywords: ("vestibular migraine" OR "migrainous vertigo" OR "migraine associated vertigo" OR "migraine related vertigo") AND ("epidemiology" OR "prevalence" OR "inheritance" OR "heritage" OR "heritability" OR "genes" OR "genetics" OR "families" OR "familial" OR "twins"). The search was limited to articles published in the last 25 years. Additional records identified through the list of references or other sources were also included.

\section{Exclusion Criteria}

Records that met the following characteristics were excluded from the review:

- Animal studies.

- Studies in child population.

- Articles published in languages other than English or Spanish.

\section{Data Collected}

Two independent reviewers (APT, PPC) analyzed the scientific papers that met the selection criteria. Each article was reviewed to extract the relevant data for the purpose of this work. The main data that were extracted from the studies were those referring to indicators of heritability, since the main objective 
of this review is to assess whether VM is a disease that has a genetic contribution. These heritability criteria in multifactorial disorders are estimated by comparing the variation of the prevalence of the disease among population with different ethnic background and by familial aggregation studies calculating the sibling recurrence risk ratio $\left(\lambda_{s}\right)$ using the Falconer formula (Wickramaratne and Hodge, 2001).

The following information was also collected from descriptive and genetic studies: first author and year of publication, country, study design, main objective, sample size, MV diagnostic criteria, ancestry, sex of patients with VM, mean age of patients with VM and mean age of VM onset. From descriptive studies information on VM prevalence, target population, and family history of MV was also extracted.

\section{Data Synthesis}

Information on the prevalence of VM have been collected in epidemiological studies. Mean values and standard deviation have been calculated for the age of onset of migraine and vertigo. Prevalence of VM in families was estimated from different studies and pooled to calculate the recurrence risk among siblings $\left(\lambda_{s}\right)$. Statistical analyses were performed using Microsoft Excel and SPPS software.

\section{Quality Assessment}

The quality of each study has been assessed through the Cochrane Collaboration Tool (Higgins et al., 2019) and the risk of bias was summarized in Supplementary Table 2. Furthermore, the quality of genetic studies has also been evaluated according to the criteria defined to assess genetic studies in quantitative traits with extreme phenotype (Amanat et al., 2020).

\section{RESULTS}

Thirty-one studies with a total sample size of 41,127 individuals were finally included in this revision, according to the eligibility criteria. A flowchart detailing the selection of studies is included in Figure 1.

\section{Cross-Sectional Studies and Case Series}

Twenty-four descriptive epidemiological studies were included (16 cross-sectional studies, 5 case series, and 3 familial studies) (Supplementary Table 3). These studies estimated the prevalence of VM in different populations, geographical areas or families and reported clinical and demographic features of this disease. Five studies were population-based, while the rest were hospital-based.

Only 5 studies mentioned the ancestry and 3 of them included data about the prevalence of VM. An earlier onset of the disease was found in families when they were compared to non-familiar VM patients.

A female preponderance was observed in VM, although four studies did not report this information. Nineteen studies reported the mean age of patients with VM, however, only 11 described the age at VM onset. Thus, familial history of VM patients was detailed in seven studies.

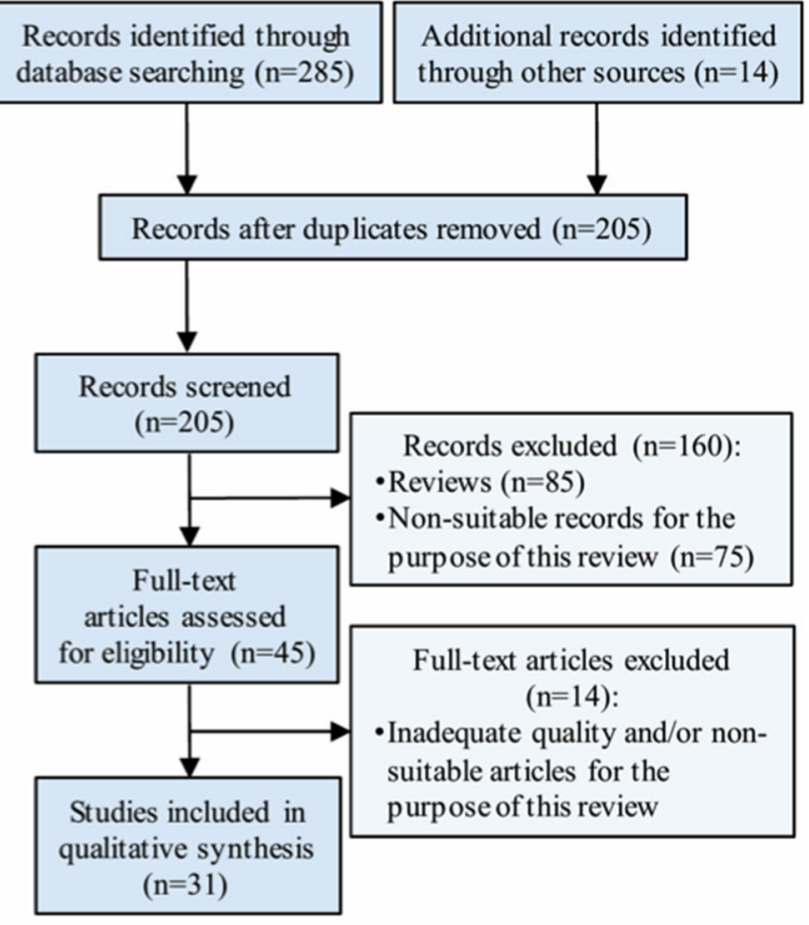

FIGURE 1 | Selection of studies.

\section{Genetic Studies}

Seven genetic studies were included (3 case-control studies and 4 genetic linkage analysis in families) (Table 1). The main purpose of these studies was to find mutations or loci in families associated with the disease. One of the case-control studies reported a significant association of the allelic variant rs770963777 in the HTR6 gene with VM in a small cohort of Han Chinese descendants. Two of the studies reported significant associations of VM with certain genome regions: a locus in chromosome $5 \mathrm{q} 35$, and the PROGINS variant of the $P R G$ gene, respectively. Another study found significant association between chromosome $22 \mathrm{q} 12$ and benign recurrent vertigo, which was a common diagnosis established for patients with migraine and episodic vertigo before the VM diagnostic criteria were established.

Three studies reported the ancestry, specifically Han Chinese in one of the studies, Caucasian in another one and German, Bosnian and Turkish in the last one. Female preponderance was also observed in all genetic studies.

\section{Prevalence of VM According to the Geographic Area or Ancestry}

Two population-based studies estimated the prevalence of VM in the general population, ranging from 0.89 to $2.70 \%$ in Germany and US, respectively. However, most studies were hospital-based and the authors estimated the prevalence of $\mathrm{VM}$ in migraine patients and in outpatient clinics, showing some differences. Five studies used the Barany Society diagnostic criteria for VM, and 
TABLE 1 | Summary of the six genetic studies in patients with vestibular migraine.

\begin{tabular}{|c|c|c|c|c|c|c|c|c|c|c|}
\hline References & Country & Study design & Main objective & Sample size & Main findings & $\begin{array}{l}\text { Diagnostic } \\
\text { criteria (VM) }\end{array}$ & Ancestry & $\begin{array}{l}\text { Gender of } \\
\text { VM patients } \\
\text { (\% women) }\end{array}$ & $\begin{array}{l}\text { Mean age of } \\
\text { VM patients } \\
\text { (years) }\end{array}$ & $\begin{array}{l}\text { Mean age of VM } \\
\text { onset (years) }\end{array}$ \\
\hline Wu et al. (2020) & China & Case-control & $\begin{array}{l}\text { To investigate the } \\
\text { association of rs } 770963777 \\
\text { in HTR6 gene with VM }\end{array}$ & $\begin{array}{l}-92 \mathrm{VM} \\
-100 \text { controls }\end{array}$ & $\begin{array}{l}\text { Significant association } \\
\text { of VM with } \\
\text { rs770963777(C/T) }\end{array}$ & Barany/IHS & Han Chinese & $52.2 \%$ & $44.2 \pm 9.3$ & Not available \\
\hline $\begin{array}{l}\text { Peddareddygari } \\
\text { et al. (2019) }\end{array}$ & USA & $\begin{array}{l}\text { Genome-wide linkage } \\
\text { analysis in one family } \\
\text { using microsatellite } \\
\text { markers }\end{array}$ & $\begin{array}{l}\text { To test whether vertigo and } \\
\text { motion sickness are } \\
\text { inherited through different } \\
\text { susceptibility genes than } \\
\text { migraine }\end{array}$ & 29 & Non-significant results & $\begin{array}{l}\text { - ICHD-I: migraine } \\
\text { - ad hoc clinical } \\
\text { criteria: vertigo } \\
\text { and motion } \\
\text { sickness }\end{array}$ & Not available & $90 \%$ & Not available & $10.5 \pm 4$ \\
\hline $\begin{array}{l}\text { Bahmad et al. } \\
\text { (2009) }\end{array}$ & USA/Brazil & $\begin{array}{l}\text { Genome-wide linkage } \\
\text { analysis in one family } \\
\text { using microsatellite } \\
\text { markers }\end{array}$ & $\begin{array}{l}\text { To map the genetic locus for } \\
\text { familial VM and to define the } \\
\text { progression of the disease } \\
\text { in one family }\end{array}$ & 23 & $\begin{array}{l}\text { Significant association } \\
\text { of VM with a region of } \\
\text { chromosome } 5 q 35\end{array}$ & Neuhauser et al. & Not available & $50 \%$ & $60.7 \pm 20.6$ & $\begin{array}{l}-12 \pm 4.7 \\
\text { (migraine) } \\
-39.2 \pm 6.2 \\
\text { (vertigo) }\end{array}$ \\
\hline Lee et al. (2008) & USA & $\begin{array}{l}\text { Genetic linkage } \\
\text { analysis in one family }\end{array}$ & $\begin{array}{l}\text { To analyze phenotypic and } \\
\text { genetic features of a family } \\
\text { with VM in order to assess } \\
\text { its inheritance pattern. }\end{array}$ & 46 & $\begin{array}{l}\text { - Non-significant results } \\
\text { - Non-significant } \\
\text { association with } \\
\text { chromosome } 11 \text { q in } \\
\text { most affected women }\end{array}$ & $\begin{array}{l}\text { - ICHD-I: migraine } \\
\text { - ad hoc criteria: } \\
\text { VM }\end{array}$ & Not available & $87.5 \%$ & $47.6 \pm 15.4$ & $\begin{array}{l}-14.7 \pm 6 \\
\text { (migraine) } \\
-36.2 \pm 9.1 \\
\text { (vertigo) } \\
-13.5 \pm 9.2 \\
\text { (simultaneous } \\
\text { onset of both } \\
\text { symptoms) }\end{array}$ \\
\hline Lee et al. (2007) & USA & Case-control & $\begin{array}{l}\text { To test the association of } \\
\text { female hormonal genes } \\
\text { (PGR and ESR1) with VM }\end{array}$ & $\begin{array}{l}-150 \mathrm{MV} \\
-145 \text { controls }\end{array}$ & $\begin{array}{l}\text { Significant association } \\
\text { of VM with PROGINS } \\
\text { variant of progesterone } \\
\text { receptor }\end{array}$ & $\begin{array}{l}\text { - IHS: migraine } \\
\text { - ad hoc clinical } \\
\text { criteria: vertigo }\end{array}$ & Caucasian & $83.4 \%$ & Not available & Not available \\
\hline $\begin{array}{l}\text { von Brevern et al. } \\
\text { (2006) }\end{array}$ & USA/Germany & Case-control & $\begin{array}{l}\text { To test whether mutations in } \\
\text { CACNA1A, ATP1A2, } \\
\text { SCN1A and CACNB4 } \\
\text { confer susceptibility to VM }\end{array}$ & $\begin{array}{l}-14 \mathrm{MV} \\
-46 \text { controls }\end{array}$ & Non-significant results & $\begin{array}{l}\text { Neuhauser et al. } \\
\text { (modified) }\end{array}$ & $\begin{array}{l}\text { German, } \\
\text { Turkish, } \\
\text { Bosnian }\end{array}$ & $64.3 \%$ & $50 \pm 11.1$ & $\begin{array}{l}-21.3 \pm 7.5 \\
\text { (migraine) } \\
-37.9 \pm 14.4 \\
\text { (vertigo) } \\
-35.3 \pm 13.4 \\
\text { (simultaneous } \\
\text { onset of both } \\
\text { symptoms) }\end{array}$ \\
\hline Lee et al. (2006) & USA & $\begin{array}{l}\text { Genome-wide linkage } \\
\text { analysis in families }\end{array}$ & $\begin{array}{l}\text { To genetically define BRV } \\
\text { and its association with } \\
\text { migraine. }\end{array}$ & 257 & $\begin{array}{l}\text { - } 31.2 \% \text { prevalence of } \\
\text { migraine and BRV } \\
\text { association } \\
\text { - Significant association } \\
\text { of chromosome 22q12 } \\
\text { with BRV }\end{array}$ & $\begin{array}{l}\text { - IHS criteria for } \\
\text { migraine } \\
\text { - ad hoc clinical } \\
\text { criteria for vertigo }\end{array}$ & Not available & $84.4 \%$ & Not available & Not available \\
\hline
\end{tabular}


TABLE 2 | Prevalence of vestibular migraine depending on geographic area and target population (outpatients clinics or hospital-based studies).

\begin{tabular}{|c|c|c|c|c|c|c|}
\hline References & Continent & Country & $\begin{array}{l}\text { Target } \\
\text { population }\end{array}$ & $\begin{array}{l}\text { Number of } \\
\text { patients }\end{array}$ & Diagnostic criteria & Prevalence of VM \\
\hline Power et al. (2018) & Oceania & Australia & $\begin{array}{l}\text { Outpatients in a } \\
\text { balance disorders } \\
\text { clinic }\end{array}$ & 90 & Barany/IHS & $\begin{array}{l}41 \% \text { definite and } \\
\text { probable VM }\end{array}$ \\
\hline Yollu et al. (2017) & Europe & Turkey & $\begin{array}{l}\text { Patients with } \\
\text { migraine }\end{array}$ & 100 & Barany/IHS & $21 \%$ definite VM \\
\hline $\begin{array}{l}\text { Hazzaa and El } \\
\text { Mowafy (2016) }\end{array}$ & Africa & Egypt & $\begin{array}{l}\text { Outpatients in a } \\
\text { dizziness clinic }\end{array}$ & 446 & Barany/IHS & $22 \%$ definite VM \\
\hline Akdal et al. (2015) & Europe & Turkey & $\begin{array}{l}\text { Patients with } \\
\text { migraine }\end{array}$ & 871 & $\begin{array}{l}\text { - ICHD-II for migraine. } \\
\text { - ad hoc clinical criteria } \\
\text { for vestibular } \\
\text { symptoms }\end{array}$ & $\begin{array}{l}\text { - } 62 \% \text { vertigo } \\
\text { - } 76 \% \text { vestibular } \\
\text { symptoms (vertigo and } \\
\text { motion sickness) }\end{array}$ \\
\hline Akdal et al. (2013) & Europe & Turkey & $\begin{array}{l}\text { Patients with } \\
\text { migraine }\end{array}$ & 1,880 & $\begin{array}{l}\text { - ICHD-II for migraine. } \\
\text { - ad hoc clinical criteria } \\
\text { for vestibular } \\
\text { symptoms }\end{array}$ & $\begin{array}{l}\text { 20.3\% vestibular } \\
\text { symptoms (vertigo } \\
\text { and/or dizziness and/or } \\
\text { motion sickness) }\end{array}$ \\
\hline $\begin{array}{l}\text { Jay-du Preez and } \\
\text { van Papendorp } \\
\text { (2011) }\end{array}$ & Africa & South Africa & $\begin{array}{l}\text { Patients visiting a } \\
\text { general } \\
\text { practitioner }\end{array}$ & 717 & Neuhauser et al. & $\begin{array}{l}1.67 \% \text { (definite and } \\
\text { probable VM) }\end{array}$ \\
\hline Uneri (2004) & Europe & Turkey & $\begin{array}{l}\text { Patients with } \\
\text { BPPV }\end{array}$ & 476 & ICHD-I for migraine & $54.8 \%$ migraine \\
\hline $\begin{array}{l}\text { Van Ombergen } \\
\text { et al. (2015) }\end{array}$ & Europe & Belgium & $\begin{array}{l}\text { Patients attending } \\
\text { an } O R L \text { clinic }\end{array}$ & 407 & Barany/IHS & $\begin{array}{l}\text { - } 4.3 \% \text { definite VM } \\
\text { - } 5.6 \% \text { probable VM }\end{array}$ \\
\hline $\begin{array}{l}\text { Vuković et al. } \\
\text { (2007) }\end{array}$ & Europe & Croatia & $\begin{array}{l}\text { Patients with } \\
\text { migraine }\end{array}$ & 327 & Neuhauser et al. & $23.2 \%$ definite VM \\
\hline $\begin{array}{l}\text { Neuhauser et al. } \\
\text { (2001) }\end{array}$ & Europe & Germany & $\begin{array}{l}\text { - Patients with } \\
\text { migraine - Patients } \\
\text { attending a } \\
\text { dizziness clinic }\end{array}$ & $\begin{array}{l}\text { - } 200 \text { with } \\
\text { migraine } \\
\text { - } 200 \\
\text { attending a } \\
\text { dizziness } \\
\text { clinic }\end{array}$ & Neuhauser et al. & $\begin{array}{l}\text { - } 9 \% \text { definite VM in } \\
\text { patients with migraine } \\
\text { - } 7 \% \text { definite VM in } \\
\text { patients attending a } \\
\text { dizziness clinic }\end{array}$ \\
\hline Cho et al. (2016) & Asia & South Korea & $\begin{array}{l}\text { Patients with } \\
\text { migraine }\end{array}$ & 631 & Barany/IHS & $\begin{array}{l}\text { - 10.3\% definite VM } \\
\text { - 2,5\% probable VM }\end{array}$ \\
\hline $\begin{array}{l}\text { Tungvachirakul } \\
\text { et al. (2014) }\end{array}$ & Asia & Thailand & $\begin{array}{l}\text { Patients attending } \\
\text { a neurotology } \\
\text { clinic }\end{array}$ & 167 & Neuhauser et al. & $34.7 \%$ definite VM \\
\hline
\end{tabular}

VM, Vestibular Migraine; IHS, International Headache Society; ICHD, International Classification of Headache Disorders; BPPV, Benign Paroxysmal Positional Vertigo.

showed a prevalence of VM ranging from $4.3 \%$ in Belgium to $22 \%$ in Egypt (Table 2).

One population-based study performed in US described that $13.9 \%$ of VM patients were black, while $79.8 \%$ of VM patients were white, which results in a significant difference. After the analysis of the results from this population-based survey, we calculated the prevalence of VM for each ethnicity, resulting in a VM prevalence of $3.13 \%$ in African descendants, $2.64 \%$ in Europeans and $1.07 \%$ in Asian descendent population.

\section{Familial Aggregation}

Three studies reported that the migraine-vertigo association was more frequent in siblings of patients with VM than in the general population.

On the other hand, some cross-sectional and case series studies described a familial history of migraine, vertigo or both among VM patients. So, a familial history of migraine was reported in $70 \%$ of $\mathrm{VM}$ patients and $21.4 \%$ of VM patients had a familial history of VM.

The sibling recurrence risk ratio $\left(\lambda_{\mathrm{s}}\right)$ for the migrainevertigo association was calculated by comparing the prevalence of this association in families with that prevalence in the general population, to assess the familial aggregation for VM (Table 3). Our results also showed a moderate familial aggregation $\left(\lambda_{\mathrm{s}}=4.31-10.42\right)$.

\section{Age of VM Onset}

We compared the age of VM onset in different studies, particularly, the age of migraine onset, the age of vertigo onset and the simultaneous onset of vertigo and migraine, including a brief analysis on sex distribution (Table 4). So, we found that the mean age of onset in patients with simultaneous presentation of vertigo and migraine was $22.7 \pm 10.4$ years; however, for patients with a metachronic presentation of symptoms, the mean age of 
TABLE 3 | Prevalence of migraine-vertigo association in families and sibling recurrence risk $\left(\lambda_{s}\right)$.

\begin{tabular}{|c|c|c|c|c|c|}
\hline References & Sample size & $\begin{array}{c}\text { Number of siblings } \\
\text { with migraine and } \\
\text { vertigo }\end{array}$ & $\begin{array}{c}\text { Total } \\
\text { number of } \\
\text { siblings }\end{array}$ & $\begin{array}{c}\text { Prevalence of } \\
\text { migraine and vertigo } \\
\text { in siblings (\%) }\end{array}$ & $\lambda_{\mathrm{s}}$ \\
\hline $\begin{array}{l}\text { Peddareddygari et al. } \\
(2019)^{\star}\end{array}$ & 29 & 4 & 15 & 26.67 & 8.33 \\
\hline Bahmad et al. (2009) & 23 & 4 & 12 & 33.33 & 10.42 \\
\hline Cha et al. (2008) & 69 & 4 & 29 & 13.79 & 4.31 \\
\hline Lee et al. (2008) & 46 & 2 & 14 & 14.29 & 4.46 \\
\hline Lee et al. (2006) & 257 & 13 & 57 & 22.81 & 7.13 \\
\hline Oh et al. (2001) & 287 & 20 & 68 & 29.41 & 9.19 \\
\hline Oliveira et al. (1997) & 19 & 5 & 18 & 27.78 & 8.68 \\
\hline Total & 730 & 52 & 213 & 24.41 & 7.63 \\
\hline
\end{tabular}

*Studies based on Barany Society diagnostic criteria for VM.

TABLE 4 | Sex distribution and age of onset (mean \pm standard deviation) of migraine, vertigo, and patients with simultaneous onset of both symptoms.

\begin{tabular}{|c|c|c|c|c|c|}
\hline References & $\begin{array}{l}\text { Number of patients with } \\
\text { VM and non- } \\
\text { simultaneous onset of } \\
\text { migraine and vertigo (sex } \\
\text { distribution, F/M) }\end{array}$ & $\begin{array}{l}\text { Age of migraine } \\
\text { onset (years) }\end{array}$ & $\begin{array}{l}\text { Age of vertigo } \\
\text { onset (years) }\end{array}$ & $\begin{array}{c}\text { Number of patients with } \\
\text { VM and simultaneous } \\
\text { onset of migraine and } \\
\text { vertigo }\end{array}$ & $\begin{array}{l}\text { Simultaneous onset for } \\
\text { migraine and vertigo } \\
\text { (years) }\end{array}$ \\
\hline *Beh et al. (2019) & 129 & - & $44.3 \pm 13.7$ & - & - \\
\hline $\begin{array}{l}\text { *Peddareddygari et al. } \\
\text { (2019) }\end{array}$ & $10(9 / 1)$ & - & $10.5 \pm 4$ & - & - \\
\hline Teggi et al. (2018) & 260 & $21.8 \pm 9$ & $37.4 \pm 13.1$ & 19 & $19.8 \pm 2.1$ \\
\hline Martínez et al. (2017) & $14(14 / 0)$ & $16.3 \pm 8.2$ & $31.7 \pm 11.8$ & 27 & $24 \pm 12$ \\
\hline *Cohen et al. (2011) & 147 & 30.7 & 38.7 & - & - \\
\hline Bahmad et al. (2009) & $6(2 / 4)$ & $12 \pm 4.7$ & $39.2 \pm 6.2$ & - & - \\
\hline Lee et al. (2008) & $6(5 / 1)$ & $14.7 \pm 6$ & $36.2 \pm 9.1$ & 2 & $13.5 \pm 9.2$ \\
\hline *Vuković et al. (2007) & $\begin{array}{c}169 \text { (migraine with } \\
\text { vestibular } \\
\text { symptoms) }\end{array}$ & - & 25.3 & - & - \\
\hline $\begin{array}{l}\text { von Brevern et al. } \\
\text { (2006) }\end{array}$ & $11(6 / 5)$ & $21.3 \pm 7.5$ & $37.9 \pm 14.4$ & 3 & $35.3 \pm 13.4$ \\
\hline $\begin{array}{l}\text { *Neuhauser et al. } \\
\text { (2001) }\end{array}$ & 33 & $22 \pm 11$ & $35 \pm 14$ & - & - \\
\hline *Oh et al. (2001) & 20 & - & $34.15 \pm 16.9$ & - & - \\
\hline Oliveira et al. (1997) & $8(5 / 3)$ & $15.5 \pm 10.1$ & - & - & - \\
\hline Female total & 41 & $15,2+/-7,4$ & $33,7+/-15,9$ & 21 & $24,8+/-12,8$ \\
\hline Male total & 14 & $19,9+/-10,1$ & $37,5+/-14,3$ & 11 & $23,6+/-13,3$ \\
\hline Total & 813 & $24 \pm 8.9$ & $35.6 \pm 12.4$ & 51 & $22.7 \pm 10.4$ \\
\hline
\end{tabular}

VM, Vestibular Migraine. *These studies do not report data on simultaneous age of onset; therefore, they were included in the "patients with non-simultaneous onset" category.

onset for migraine was $24 \pm 8.9$ years, and $35.6 \pm 12.4$ year for vertigo.

To sum up, we observed that 6 studies recorded data about audiological symptoms in VM. The prevalence and distribution of these audiological symptoms in VM is shown in Table 5.

\section{DISCUSSION}

The association between migraine and vertigo has been known for a long time; however, it has not been considered as an independent entity until the last decade (56). The current diagnostic criteria were published in 2012 (Lempert et al., 2012), therefore, only 8 of the studies included in this revision applied these criteria for the diagnosis of VM. The criteria proposed by Neuhauser et al. (2001) were reported in 8 of the studies, and in the rest of the publications, the authors used ICHD criteria for migraine and ad-hoc clinical criteria for vertigo. One of the family studies did not report any diagnostic criteria, but later this family was reported as familial VM.

There are several evidence to support heritability in complex traits such as vestibular disorders: (a) differences in the prevalence of the condition according to the ethnic background; 
TABLE 5 | Prevalence of audiological symptoms in patients with VM.

\begin{tabular}{|c|c|c|c|c|}
\hline References & $N$ & Audiological symptoms reported & $\begin{array}{l}\text { Number of patients with } \\
\text { otological symptoms }\end{array}$ & Prevalence \\
\hline \multirow[t]{3}{*}{ Teggi et al. (2018) } & 252 & Tinnitus (during vertigo attacks) & 27 & 0.11 \\
\hline & & Ear fullness (during vertigo attacks) & 22 & 0.09 \\
\hline & & Hearing loss (during vertigo attacks) & 10 & 0.04 \\
\hline \multirow[t]{3}{*}{ Yollu et al. (2017) } & 21 & $\begin{array}{l}\text { Sensorineural hearing loss (SNHL) } \\
\text { according to average hearing threshold }\end{array}$ & 2 & 0.09 \\
\hline & & SNHL acc. to low frequency & 6 & 0.28 \\
\hline & & SNHL acc. to high frequency & 11 & 0.52 \\
\hline \multirow[t]{3}{*}{ Van Ombergen et al. (2015) } & 65 & Tinnitus & 35 & 0.54 \\
\hline & & Decreased hearing & 3 & 0.05 \\
\hline & & Hearing loss & 5 & 0.25 \\
\hline $\begin{array}{l}\text { Cha et al. (2008) (families } \\
\text { study) }\end{array}$ & 20 & Migraine and MD symptoms (migraine/MD) & 19 & 0.13 \\
\hline Lee et al. (2007) & 150 & Migraine and MD symptoms (migraine/MD) & 19 & 0.13 \\
\hline \multirow[t]{4}{*}{ Neuhauser et al. (2006) } & 33 & $\begin{array}{l}\text { Cochlear symptoms (during vertigo } \\
\text { attacks) }\end{array}$ & 12 & 0.36 \\
\hline & & Tinnitus (during vertigo attacks) & 5 & 0.15 \\
\hline & & Aural fullness (during vertigo attacks) & 5 & 0.15 \\
\hline & & Hearing loss (during vertigo attacks) & 3 & 0.09 \\
\hline \multirow[t]{2}{*}{ Total } & 541 & Hearing loss & 46 & 0.085 \\
\hline & 350 & Tinnitus & 67 & 0.191 \\
\hline
\end{tabular}

(b) familial aggregation with early onset and anticipation; and (c) high concordance of the phenotype in monozygotic twins and adoptees with biological parents when they are compared with dizygotic twins or adoptive parents, respectively (GallegoMartinez et al., 2018).

The population-based study from Formeister et al. (2018) showed a higher prevalence of VM in African American or Europeans than in Asian descendent population, suggesting a possible genetic contribution. It should be interesting to compare the prevalence of VM in East Asia in a large cohort with the Asian American descendent to assess the environmental effect on VM.

Moreover, the prevalence of VM in migraine patients seems to be higher in European countries (23\% in Croatia, $21 \%$ in Turkey) (Vuković et al., 2007; Yollu et al., 2017) than in Asian countries (10\% in South Korea) (Cho et al., 2016). However, the diagnosis of VM in neurotology clinics shows a great variation ranging from a $7 \%$ reported in Germany (Neuhauser et al., 2001), 22\% in Egypt (Hazzaa and El Mowafy, 2016) to $41 \%$ in Australia (Power et al., 2018). These data suggest differences in the diagnostic criteria used rather than ethnic differences in $\mathrm{VM}$ and evidence that population-based studies are needed to estimate the prevalence of VM.

Familial aggregation is usually reported in rare diseases, and suggests a combined effect of genetic and environmental factors (Requena et al., 2014a). This type of studies compares the prevalence of a disease in individuals of the same generation within a family with the prevalence of that disease in general population. In order to do this, the sibling recurrence risk ratio $\left(\lambda_{s}\right)$ is calculated. That proportion allows us to know how many times the disease is more frequent between the siblings of the affected individual, as compared with the general population. Our systematic review show that familial studies (Oliveira et al., 1997; Oh et al., 2001; Lee et al., 2006, 2008; Cha et al., 2008; Bahmad et al., 2009; Peddareddygari et al., 2019) showed a higher prevalence of the migraine-vertigo association than the observed prevalence of that association in the general population (3.2\%) (Neuhauser et al., 2001), and also higher than the 2.7\% prevalence of VM in general population (Formeister et al., 2018). We calculated $\lambda_{s}$ for the migraine-vertigo association, which resulted in a risk ranging between 4-10 times higher than in general population.

Most of the studies included in this review reported information about age of onset of migraine and vertigo. Some of them described a significantly lower age of onset in patients with VM, as compared with controls affected either by migraine or vertigo (Vuković et al., 2007; Akdal et al., 2013). By comparing the age of VM onset in several studies, we found that there was an earlier onset of symptoms in those patients with simultaneous presentation of migraine and vertigo, as compared with those with metachronic onset of symptoms.

Early and simultaneous onset of symptoms observed in familial VM suggests genetic anticipation, a phenomenon of progression of severity of an inherited disorder in successive generations frequently found in neurological disorders and associated with expansion of nucleotide repeats (Carpenter, 1994). Teggi et al. (2018) reported a significantly lower age of migraine onset in patients with a familial history of migraine or VM, as compared with those without it. These results were also reported in some of the included familial studies (Lee et al., 2008; Bahmad et al., 2009; Peddareddygari et al., 2019), 
in which age of migraine onset seems to be lower than in non-familial cases.

The genetic association studies retrieved have reported allelic variants in the HTR6 and PRG genes associated with VM (Lee et al., 2007; Wu et al., 2020). Replication studies are needed to validate these results.

The genetic contribution to vestibular diseases, including VM is largely unknown (Requena et al., 2014b; Gallego-Martinez et al., 2018). The application of high throughput sequencing technologies in multiplex families with deep phenotyping will target candidate genes and clarify disease mechanisms and facilitate the genetic diagnosis of VM in clinical practice (Di Resta and Ferrari, 2018; Prodan Žitnik et al., 2018).

\section{Limitations of This Study}

Most of the genetic studies included in this revision are based on linkage analysis of multicase families. The majority of them were published more than a decade ago and were performed before the development of high-throughput DNA massively parallel sequencing technology. Only two of them found 2 loci associated with VM, but none of them found the causal mutations.

The current diagnostic criteria for VM were published in 2012, so previous studies applied different probably broader criteria. This variability in the diagnostic criteria is a selection bias that might influence the estimated prevalence and therefore, could limit the comparability between studies. Moreover, the number of studies analyzing VM heritability could be considered low, so few of them share the same variables, resulting in a limited comparability.

\section{Future Perspectives}

This systematic review provides some evidences to support a genetic contribution in VM, including familial aggregation. There is a need to perform twins and adoptees studies to

\section{REFERENCES}

Akdal, G., Baykan, B., Ertaş, M., Zarifoğlu, M., Karli, N., Saip, S., et al. (2015). Population-based study of vestibular symptoms in migraineurs. Acta Otolariyngol. 135, 435-439. doi: 10.3109/00016489.2014. 969382

Akdal, G., Ozge, A., and Ergör, G. (2013). The prevalence of vestibular symptoms in migraine or tension-type headache. J. Vestib. Res. 23, 101-106. doi: 10.3233/VES-130477

Amanat, S., Requena, T., and Lopez-Escamez, J. A. (2020). A systematic review of extreme phenotype strategies to search for rare variants in genetic studies of complex disorders. Genes (in press).

Bahmad, F., DePalma, S. R., Merchant, S. N., Bezerra, R. L., Oliveira, C. A., Seidman, C. E., et al. (2009). Locus for familial migrainous vertigo disease maps to chromosome 5q35. Ann. Otol. Rhinol. Laryngol. 118, 670-676. doi: $10.1177 / 000348940911800912$

Beh, S., Masrour, S., Smith, S., and Friedman, D. (2019). The spectrum of vestibular migraine: clinical features, triggers and examination findings. Headache 59, 727-740. doi: 10.1111/head.13484

Carpenter, N. J. (1994). Genetic anticipation. expanding tandem repeats. Neurol. Clin. 12, 683-697. doi: 10.1016/S0733-8619(18)30071-9

Cha, Y. H., Kane, M. J., and Baloh, R. W. (2008). Familial clustering of migraine, episodic vertigo, Ménière's disease. Otol. Neurotol. 29, 93-96. doi: $10.1097 / \mathrm{mao} .0 \mathrm{~b} 013 \mathrm{e} 31815 \mathrm{c} 2 \mathrm{abb}$ estimate heritability in VM. Therefore, whole genome sequencing studies in multicase families are needed to find genetic variants conferring susceptibility to this disease.

\section{CONCLUSIONS}

1. Clinical studies seem to report differences in the prevalence of VM according to the ethnic origin and country.

2. Family aggregation studies show a higher prevalence of migraine and vertigo in families compared to general population, with a moderate risk of recurrence among siblings and possible anticipation.

3. Since there are no twins studies published, there is a need to perform such studies to estimate heritability in VM.

\section{AUTHOR CONTRIBUTIONS}

JL-E conceived the study design and develop the scientific arguments. AP-T and PP-C performed literature search, quality assessment of the studies, and interpretation of data. All authors drafted the manuscript and revised the final version.

\section{ACKNOWLEDGMENTS}

The authors wish to thank Juan Manuel Espinosa Sánchez MD at Hospital Universitario Virgen de las Nieves for his support in the literature search.

\section{SUPPLEMENTARY MATERIAL}

The Supplementary Material for this article can be found online at: https://www.frontiersin.org/articles/10.3389/fgene. 2020.00954/full\#supplementary-material

Cho, S. J., Kim, B. K., Kim, B. S., Kim, J. M., Kim, S. K., Moon, H. S., et al. (2016). Vestibular migraine in multicenter neurology clinics according to the appendix criteria in the third beta edition of the international classification of headache disorders. Cephalalgia 36, 454-462. doi: 10.1177/0333102415597890

Cohen, J., Bigal, M., and Newman, L. (2011). Migraine and vestibular symptoms - identifying clinical features that predict "vestibular migraine". Headache 51, 1393-1397. doi: 10.1111/j.1526-4610.2011.01934.x

de Boer, I., van den Maagdenberg, A. M. J. M., and Terwindt, G. M. (2019). Advance in genetics of migraine. Curr. Opin. Neurol. 32, 413-421. doi: 10.1097/WCO.0000000000000687

Di Resta, C., and Ferrari, M. (2018). Next generation sequencing: from research area to clinical practice. EJIFCC 29, 215-220.

Espinosa-Sanchez, J. M., and Lopez-Escamez, J. A. (2015). New insights into pathophysiology of vestibular migraine. Front. Neurol. 6:12. doi: 10.3389/fneur.2015.00012

Formeister, E. J., Rizk, H. G., Kohn, M. A., and Sharon, J. D. (2018). The Epidemiology of vestibular migraine: a population-based survey study. Otol. Neurotol. 39, 1037-1044. doi: 10.1097/MAO.0000000000001900

Gallego-Martinez, A., Espinosa-Sanchez, J. M., and Lopez-Escamez, J. A. (2018). Genetic contribution to vestibular diseases. J. Neurol. 265(Suppl. 1), 29-34. doi: 10.1007/s00415-018-8842-7

Hazzaa, N., and El Mowafy, S. S. (2016). Clinical features of vestibular migraine in Egypt. Egypt. J. Ear Nose Throat Allied Sci. 17, 17-21. doi: 10.1016/j.ejenta.2015.12.002 
Headache Classification Committee of the International Headache Society (2018). (IHS) The international classification of headache disorders, 3rd edition. Cephalalgia. 38, 1-211. doi: 10.1177/0333102417738202

Higgins, J., Thomas, J., Chandler, J., Cumpston, M., Li, T., Page, M., et al. (2019). Cochrane Handbook for Systematic Reviews of Interventions version 6.0 Cochrane. Chichester, UK: John Wiley \& Sons.

Jay-du Preez, T., and van Papendorp, D. (2011). Migraine-associated vertigo and dizziness as presenting complaint in a private general medical practice. South Afr. Family Pract. 53, 165-169. doi: 10.1080/20786204.2011.10874079

Kim, J. S., Yue, Q., Jen, J. C., Nelson, S. F., and Baloh, R. W. (1998). Familial migraine with vertigo: no mutations found in CACNA1A. Am. J. Med. Genet. 79, 148-151. doi: 10.1002/(SICI)1096-8628(19980901)79:2<148::AIDAJMG11>3.0.CO;2-J

Knezevic, N. N., Tverdohleb, T., Knezevic, I., and Candido, K. D. (2018). The role of genetic polymorphisms in chronic pain patients. Int. J. Mol. Sci. 19:1707. doi: 10.3390/ijms19061707

Lee, H., Jen, J. C., Cha, Y. H., Nelson, S. F., and Baloh, R. W. (2008). Phenotypic and genetic analysis of a large family with migraine-associated vertigo. Headache 48 , 1460-1467. doi: 10.1111/j.1526-4610.2007.01002.x

Lee, H., Jen, J. C., Wang, H., Chen, Z., Mamsa, H., Sabatti, C., et al. (2006). A genome-wide linkage scan of familial benign recurrent vertigo: linkage to 22q12 with evidence of heterogeneity. Hum. Mol. Genet. 15, 251-258. doi: $10.1093 / \mathrm{hmg} / \mathrm{ddi} 441$

Lee, H., Sininger, L., Jen, J. C., Cha, Y. H., Baloh, R. W., and Nelson, S. F. (2007). Association of progesterone receptor with migraine-associated vertigo. Neurogenetics 8, 195-200. doi: 10.1007/s10048-007-0091-3

Lempert, T., Olesen, J., Furman, J., Waterston, J., Seemungal, B., Carey, J., et al. (2012). Vestibular migraine: diagnostic criteria. J. Vestib. Res. 22, 167-172. doi: 10.3233/VES-2012-0453

Li, V., McArdle, H., and Trip, S. A. (2019). Vestibular migraine. BMJ 366:14213. doi: 10.1136/bmj.14213

Martínez, E., Ruiz-Piñero, M., de Lera, M., Barón, J., Pedraza, M., and GuerreroPeral, A. (2017). Clinical characteristics of vestibular migraine: considerations in a series of 41 patients. Rev. Neurol. 64, 1-6. doi: 10.33588/rn.6401.2016164

Moher, D., Liberati, A., Tetzlaff, J., Altman, D. G., and Group, P. (2009). Preferred reporting items for systematic reviews and meta-analyses: the PRISMA statement. J. Clin. Epidemiol. 62, 1006-1012. doi: 10.1016/j.jclinepi.2009. 06.005

Mulder, E. J., Van Baal, C., Gaist, D., Kallela, M., Kaprio, J., Svensson, D. A., et al. (2003). Genetic and environmental influences on migraine: a twin study across six countries. Twin Res. 6, 422-431. doi: 10.1375/1369052037703 26420

Neuhauser, H., Leopold, M., von Brevern, M., Arnold, G., and Lempert, T. (2001). The interrelations of migraine, vertigo, migrainous vertigo. Neurology 56, 436-441. doi: 10.1212/WNL.56.4.436

Neuhauser, H. K., Radtke, A., von Brevern, M., Feldmann, M., Lezius, F., Ziese, T., et al. (2006). Migrainous vertigo: prevalence and impact on quality of life. Neurology 67, 1028-1033. doi: 10.1212/01.wnl.0000237539.09942.06

Oh, A. K., Lee, H., Jen, J. C., Corona, S., Jacobson, K. M., and Baloh, R. W. (2001). Familial benign recurrent vertigo. Am. J. Med. Genet. 100, 287-291. doi: 10.1002 /ajmg.1294

Oliveira, C. A., Bezerra, R. L., Araújo, M. F., Almeida, V. F., and Messias, C. I. (1997). Menière's syndrome and migraine: incidence in one family. Ann. Otol. Rhinol. Laryngol. 106, 823-829. doi: 10.1177/000348949710601004

Peddareddygari, L. R., Kramer, P. D., Hanna, P. A., Levenstien, M. A., and Grewal, R. P. (2019). Genetic analysis of a large family with migraine, vertigo, motion sickness. Can. J. Neurol. Sci. 46, 512-517. doi: 10.1017/cjn.2019.64

Power, L., Shute, W., McOwan, B., Murray, K., and Szmulewicz, D. (2018). Clinical characteristics and treatment choice in vestibular migraine. J. Clin. Neurosci. 52, 50-53. doi: 10.1016/j.jocn.2018.02.020

Prodan Žitnik, I., Cerne, D., Mancini I, Simi, L., Pazzagli, M., Di Resta, C., et al. (2018). Personalized laboratory medicine: a patient-centered future approach. Clin. Chem. Lab. Med. 56, 1981-1991. doi: 10.1515/cclm2018-0181

Rainero, I., Vacca, A., Govone, F., Gai, A., Pinessi, L., and Rubino, E. (2019). Migraine: genetic variants and clinical phenotypes. Curr. Med. Chem. 26, 6207-6221. doi: 10.2174/0929867325666180719120215
Requena, T., Espinosa-Sanchez, J., and Lopez-Escamez, J. (2014b). Genetics of dizziness: cerebellar and vestibular disorders. Curr. Opin. Neurol. 27, 98-104. doi: 10.1097/WCO.0000000000000053

Requena, T., Espinosa-Sanchez, J. M., Cabrera, S., Trinidad, G., Soto-Varela, A., Santos-Perez, S., et al. (2014a). Familial clustering and genetic heterogeneity in Meniere's disease. Clin. Genet. 85, 245-252. doi: 10.1111/cge.12150

Russell, M. B., Iselius, L., and Olesen, J. (1996). Migraine without aura and migraine with aura are inherited disorders. Cephalalgia 16, 305-309. doi: 10.1046/j.1468-2982.1996.1605305.x

Stewart, W. F., Bigal, M. E., Kolodner, K., Dowson, A., Liberman, J. N., and Lipton, R. B. (2006). Familial risk of migraine: variation by proband age at onset and headache severity. Neurology 66, 344-348. doi: 10.1212/01.wnl.0000196640.71600.00

Sutherland, H. G., and Griffiths, L. R. (2017). Genetics of migraine: insights into the molecular basis of migraine disorders. Headache 57, 537-569. doi: $10.1111 /$ head.13053

Teggi, R., Colombo, B., Albera, R., Asprella Libonati, G., Balzanelli, C., Batuecas Caletrio, A., et al. (2018). Clinical features, familial history, and migraine precursors in patients with definite vestibular migraine: the VM-phenotypes projects. Headache 58, 534-544. doi: 10.1111/head.13240

Tungvachirakul, V., Lisnichuk, H., and O'Leary, S. (2014). Epidemiology of vestibular vertigo in a neuro-otology clinic population in Thailand. J. Laryngol. Otol. 128, S31-S38. doi: 10.1017/S0022215113003484

Ulrich, V., Gervil, M., Kyvik, K. O., Olesen, J., and Russell, M. B. (1999). The inheritance of migraine with aura estimated by means of structural equation modelling. J. Med. Genet. 36, 225-227.

Uneri, A. (2004). Migraine and benign paroxysmal positional vertigo: an outcome study of 476 patients. Ear Nose Throat J. 83, 814-815. doi: $10.1177 / 014556130408301211$

Van Ombergen, A., Van Rompaey, V., Van De Heyning, P., and Wuyts, F. (2015). Vestibular migraine in an otolaryngology clinic: prevalence, associated symptoms, and prophylactic medication effectiveness. Otol. Neurotol. 36, 133-138. doi: 10.1097/MAO.0000000000000596

von Brevern, M., Radtke, A., Lezius, F., Feldmann, M., Ziese, T., Lempert, T., et al. (2007). Epidemiology of benign paroxysmal positional vertigo: a population based study. J. Neurol. Neurosurg. Psychiatr. 78, 710-715. doi: 10.1136/jnnp.2006.100420

von Brevern, M., Ta, N., Shankar, A., Wiste, A., Siegel, A., Radtke, A., et al. (2006). Migrainous vertigo: mutation analysis of the candidate genes CACNA1A, ATP1A2, SCN1A, and CACNB4. Headache 46, 1136-1141. doi: 10.1111/j.1526-4610.2006.00504.x

Vuković, V., Plavec, D., Galinović I., Lovrencić-Huzjan, A., Budisi,ć M., and Demarin, V. (2007). Prevalence of vertigo, dizziness, and migrainous vertigo in patients with migraine. Headache 47, 1427-1435. doi: $10.1111 / j .1526-4610.2007 .00939 . x$

Wickramaratne, P., and Hodge, S. (2001). Estimation of sibling recurrence-risk ratio under single ascertainment in two-child families. Am. J. Hum. Genet. 68, 807-812. doi: 10.1086/318784

Wu, X., Qiu, F., Wang, Z., Liu, B., and Qi, X. (2020). Correlation of 5-HTR6 gene polymorphism with vestibular migraine. J. Clin. Lab. Anal. 34:e23042. doi: $10.1002 /$ jcla. 23042

Yollu, U., Uluduz, D. U., Yilmaz, M., Yener, H. M., Akil, F., Kuzu, B., et al. (2017). Vestibular migraine screening in a migraine-diagnosed patient population, and assessment of vestibulocochlear function. Clin. Otolaryngol. 42, 225-233. doi: $10.1111 /$ coa.12699

Conflict of Interest: The authors declare that the research was conducted in the absence of any commercial or financial relationships that could be construed as a potential conflict of interest.

Copyright $(2020$ Paz-Tamayo, Perez-Carpena and Lopez-Escamez. This is an openaccess article distributed under the terms of the Creative Commons Attribution License (CC BY). The use, distribution or reproduction in other forums is permitted, provided the original author(s) and the copyright owner(s) are credited and that the original publication in this journal is cited, in accordance with accepted academic practice. No use, distribution or reproduction is permitted which does not comply with these terms. 